\title{
Implementation of the principle of sale and purchase transactions through MLM in Brand Branch (BC) PT. Herba Penawar Alwahida Indonesia (HPAI) Tanjungbalai
}

\author{
Asmuni $^{1}$, Syahnan $^{2}$, Asyura $^{3}$ \\ 1,2,3 Universitas Islam Negeri Sumatera Utara, Indonesia \\ asyuraaprilda.1974@gmail.com
}

\begin{abstract}
Products are "goods and / or services related to food, beverages, drugs, cosmetics, chemical products, biological products, genetically engineered products, as well as used goods that are used, used or utilized by the public", while the halal certificate is a certificate issued by the Central or Provincial MUI regarding the case of a food product, foodstuff, beverage and medicine and cosmetics produced by the company after being examined and declared halal by an institution authorized to issue a halal product certification. In Article 4 of Law No. 33 of 2014 concerning the guarantee of halal products it states that "Products that enter, circulate and are traded in the territory of Indonesia must be certified halal". Normatively, the article clearly stipulates that drugs that enter, circulate and are traded in the territory of Indonesia must be guaranteed halal. However, the halal certification process for medicines in Indonesia is waiting for a long time due to various dynamics, this is the content of researchers seeing the gap between Law Number 33 of 2014 and the current reality, we should be able to reflect on other countries as well. Which is more advanced than Indonesia regarding halal certification?
\end{abstract}

\section{Keywords}

dynamics, halal certification, medicinal products

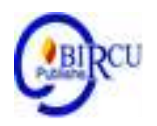

\section{Introduction}

Marketing is a process of planning and execution, starting from the conception stage, pricing, promotion, to the distribution of goods, ideas and services, to make exchanges that satisfy the individual and his institutions. (Dianto, 2020)

According to Tjiptono in Marlizar (2020) marketing performance is a function that has the greatest contact with the external environment, even though the company only has limited control over the company's environment. Performance is the result that has been achieved from what has been done by the owner or manager in running the business. Marketing performance can be measured by using sales growth, customer growth and product success to measure the impact of the strategy adopted by the company.

Promotion strategy is a concept that is close to communication science. In the promotion, there are various forms of communication learned in communication science such as advertising, publicity, communication from mouth to mouth, personal sales, and direct marketing. (Amin, 2019)

The presence of the MLM HNI HPAI company also colors the economic aspects of the people in Indonesia. With the presence of the MLM HNI HPAI, the Indonesian people have a new platform to improve their economic situation. From time to time, the number of HNI HPAI agents continues to increase. This can be seen from the higher number of ID numbers. 
HNI HPAI was officially established in 2012, previously this company was called HPA because it joined Malaysia. After parting with Malaysia, HPA changed its name to HPAI, which stands for Herba Penawar Al-Wahida Indonesia.

HNI HPAI is a company engaged in the health sector by providing medicines derived from natural herbs without any chemical elements in them. So that these drugs are safe for consumption in the long term.

The important essence of the MLM HNI HPAI Company is the sale of a product. MLM HNI HPAI in selling its products uses the services of agents who have been registered with the MLM Company. Product sales made by an MLM HNI HPAI company must also follow religious rules such as the fulfillment of contract elements, no gharar elements in the contract, etc. which are included in the law of sale and purchase so that MLM is lawful in Islam.

Including what is prohibited in the MLM HNI HPAI is selling products to consumers who have not registered to become members of the MLM HNI HPAI Company at a price member. Even though the price should not be the same between members and non-members. If the consumer wants to buy at a member price, the consumer must register as a member. The reality in the field is that there are agents who sell products at member prices to consumers who are not yet members.

Products that are traded in MLM HNI HPAI have physical goods and points from items contained in online sales. This item points will be exchanged by the company in the form of money according to the provisions. Therefore, every agent who sells products in MLM HNI HPAI must know this so that no consumer is harmed by the loss of points from a product from the goods he bought and this is also a special attraction in selling MLM HNI HPAI that is not in other sales in general. If this continues to be done by "unscrupulous" agents in the MLM HNI HPAI Company, it is certain that the MLM HNI HPAI company will not be able to progress and develop rapidly.

In fact, there are also agents of the MLM HNI HPAI company that sell a product to consumers but differ between physical products and those in online sales. even though they should be the same as those sold in the field and those sold online. Because even though two different products have the same points, sometimes the two products are not the same in price. In this case, this means that the agent has eaten the property of the consumer in vanity which is prohibited by Islamic law.

If this is sustainable, consumers will feel cheated because the price paid is not suitable for what is online. If the consumer is also an agent who sells products to other people in the environment or in his network, the consumers will feel cheated by the agent so that this "fraud" will form a sustainable relay and at its peak, consumers will not trust the MLM HNI HPAI.

\section{Review of Literatures}

\subsection{Definition of Shari'ah MLM}

MLM stands for Multi Level Marketing which comes from English. Multi word means a lot, Level means level or level and Marketing means marketing. So the term MLM can be interpreted as multi-tiered or multilevel marketing. The approach used in MLM is direct selling (direct selling), meaning that direct selling makes goods from the company directly accessible to consumers at the same price. For example, an item costs Rp. 10,000 from the company, so when it reaches consumers the price will remain $\mathrm{Rp}$. 10,000. The income that should have been enjoyed by a single dealer, wholesaler and retailer is now enjoyed by fellow consumers through bonuses. 
"MLM can also be interpreted as a way of commerce related to marketing which is carried out by many levels (levels) which are commonly known as the upline (top level) and downline (lower level) people will be called an upline if they have a downline." 36 Someone who wants to join becomes a member of an MLM company then surely he will have an upline. Because through this upline someone can join to become a member of an MLM company.

Therefore, it is said to be an MLM company because in its system there are tiered or multilevel sales. In its marketing system, MLM positions all its agents or customers into marketing relationships so that they can both benefit. Businesses using MLM are networkdriven, the wider the network, the wider the marketing that can be done and the bigger the bonuses you will get.

MLM can also be called Network Marketing. This is because more and more members of the MLM Company or organization form a network or network where this network is the marketing system of this MLM Company. This network consists of members or groups of people who work to do marketing. So, members in the company who do marketing to other prospective members or new members.

These are the principles in shari'ah MLM, namely monotheism in the sense that every activity in MLM must not conflict with the values of tawheed such as superstition, khurafat and so on; morals, namely the MLM Company that displays ethics and politeness in its corporate events and muamalah, namely fulfilling muamalah rules that have been established by religion. Conversely, if an MLM company does not have a basis for these values, then the MLM is not said to be a syari'ah MLM.

\subsection{Differences between Islamic MLM and Conventional MLM}

DSN MUI has issued fatwa number 75 of 2009 concerning direct selling with sharia levels (PLBS) or in Arabic called At-Taswiq Asy-Syabakiy which includes MLM in order to be worth sharia must meet the following criteria:

1. There are real transaction objects that are traded in the form of goods or service products;

2. The traded goods or service products are not something that is prohibited and / or that are used for something that is haram;

3. Transactions in this trade do not contain elements of gharar, maysir, usury, dharar, dzulm, immorality.

4. There is no excessive mark-up, so that it is detrimental to consumers because it is not commensurate with the quality / benefits obtained;

5. The commission given by the company to members in both size and shape must be based on real work performance which is directly related to the volume or value of the sale of goods or service products, and must be the main income of the business partner in PLBS;

6. Bonuses given by the company to members (business partners) must be clear in the amount when a transaction (contract) is made in accordance with the sales target of goods and / or service products set by the company;

7. There may be no passive commissions or bonuses that are earned on a regular basis without providing guidance and or selling goods and or services;

8. Giving commissions or bonuses by the company to members (business partners) does not cause ighra.

9. There is no exploitation and injustice in the distribution of bonuses between the first member and the next member;

10. The membership recruitment system, forms of awards and ceremonial events carried out do not contain elements that are contrary to aqidah, sharia and noble morals, such as shirk, cult, immorality and others; 
11. Every business partner who recruits membership is obliged to provide guidance and supervision to the recruited member;

12. Do not do money game activities. 160

\section{Reseach Methods}

HPA or Herba Penawar Alwahida is the largest Islamic network marketing company in the world. Its products are very focused on herbs and health foods that are halal and Toyyib. Currently, all HPA products have received a Good Manufacturing Product (GMP) certificate from WHO. This certificate is proof of the excellence of HPA products and is accepted by more than 30 countries in the world.

This company was founded by Mr. H Ismail bin $\mathrm{H}$ Ahmad who came from $\mathrm{Kg}$. Mat Ayer, Perlis which at that time was better known by the traditional name Al Wahida. After 8 years of operation, finally HPA Industries sdn. Bhd. Inaugurated on July 15, 1995.

HPA entered Indonesia on 20 May 2000 with its main partner PT Wahida Indonesia as the main manager of HPA Indonesia management and distribution of HPA products in Indonesia. Then in January 20031 HPA factory was established in South Jakarta.

In addition to obtaining a GMP (Good Manufacturing Practice) certificate, the Ministry of Industry and Trade, the Director General of POM and the Ministry of Health of the Republic of Indonesia are listed as imported traditional medicines not as food supplements, Pakistani Halal Gel (as wrapping gelatin), Sirim ISO also received approval from The best foods are those that fulfill both the halal and thayyib properties.

PT. Herba Penawar Alwahida Indonesia, which became known as HPAI, is one of the Halal Network Business companies in Indonesia that focuses on herbal products. HPAI in accordance with the deed of establishment of the Company, was officially established on March 19, 2012.

HPAI was built from a long struggle which aims to promote halal and quality products based on Thibbunnabawi, as well as in order to ground, advance, and actualize the Islamic economy in Indonesia through entrepreneurship.

\section{Discussion}

The contract in Islamic MLM uses several contracts wrong only one is contract bai / murabahah. In the terminology of buying and selling fiqh is called al-bai ' which means selling, replacing, and exchanging something for something else. The word al-bai 'includes two definitions, namely selling (al-bai ') and buying (al-syira'). Jumhur ulama said that buying and selling that did not fulfill the pillars was illegal buying and selling, while Imam Hanafi said that the sale and purchase was deemed damaged. The scholars argued that there were four pillars of buying and selling, namely:

1. The seller is required to be sensible, mature, not forced.

2. Buyers are required to be sensible, mature, not forced.

3. Sighat (consent-qobul) that isstatement from seller and buyer.

4. Buy and sell objects or goods.

The findings in the field show that the whole principles of buying and selling transactions through MLM have been fulfilled by agents of HNI HPAI agents. All agents (30 people) of HNI HPAI who have become stock agents who are suppliers of goods or in other words, if they are connected with the terms of sale and purchase, are sellers.

Details of recruiting members at Hni Tanjungbalai branch are using a process established by management, namely someone who is a prospective member must provide the 
data. Then the data is recorded by the officer at the Tanjungbalai branch brand after which the officer submits the data to the Branch Brand operator to be registered online. After being registered online, that person will get a membership number that is different from other people. There are two types of registration fees, there are Rp. 10,000, - (ten thousand) and some Rp. 30,000, - (thirty thousand) Maybe Rp. 10,000, - (ten thousand) or Rp. 30,000, (thirty thousand) we can buy a stamps of meatballs, but that will only end there.

Among the benefits are:

1. Get HNI ID and Discount card, valid as long as the earth is still there and as long as the company is still standing, valid throughout Indonesia, Asean and in various countries around the world. ID cards were chosen because they are easier for the public to accept. Those who join pay Rp. 10,000, - (ten thousand) will get a virtual card instead of a physical card that can be accessed via the AVO online respectively from a cellphone or laptop, if you pay a price of Rp. 30,000, - (thirty thousand) then you will get a card in physical form, this card is valid anywhere in all countries where there is a halal mart and is also valid as long as the earth is still around and as long as the HNI is still standing because it can be inherited to a spouse or descendants and function as a discount card to get discount and points for every product purchase. "If you want to compare it to K-Link products, they become members with a fee of between Rp. 50,000, - (fifty thousand) to Rp. 250,000, - (two hundred and fifty thousand)."

2. Got two books, namely a success guide and a product catalog. If you register by paying Rp. 10,000, - (ten thousand) will get a virtual book that can be accessed and can be downloaded. If you register with Rp. 30,000 (thirty thousand) then you will get two physical books in addition to the virtual book.

3. Get the AVO website (Virtual Office Agent) if you do business conventionally, it's not only trading but also making the accounting system, system administration and product logistics. But at HNI HPAI the company has provided it all without paying anything for an AVO service. AVO has many functions, including seeing our personal data as registered agents in the company, monthly bonus statement data in details of transfers or payments, network data of all partners in our group to any level, turnover data of all partners in the group in real time.

4. Can access distribution channels throughout Indonesia.

5. Get a discount or member price wherever you shop at the HNI HPAI halal mart.

6. Get business assistance.

Namely getting business assistance from a mentor or leader so that you can achieve success indefinitely and anytime. In terms of buying and selling, a seller is required to be sensible, namely to have a sound mind so that he is aware of the activities he is doing; baligh, namely having reached adulthood in Islamic rules so that at this age a person has to bear the consequences of his actions, whether good in nature so that he gets rewarded or evil in nature so that he gets a sin retribution; not forced, namely there is no coercion from other parties to make a sale and purchase.

Based on interviews conducted with HNI HPAI agents who have become stock agents so that they become providers of goods (sellers) which in management terms are called halal Mart is a sensible person, mature and not compelled to 282. Furthermore, from the results of the interview, it was also found that all buyers who shop at stock agents (providers of goods / sellers) are people who have fulfilled the conditions in terms of buying and selling, namely sensible, baligh; everyone who wants to join to become a member or member of HNI HPAI is registered by filling out the data form available on HSIS Online. Agents who register new prospective members or members of the HNI HPAI must fill in data on HSIS Online based on the data seen from the KTP. In government administration, a person can have a KTP if the 
person has reached the age of 17. So in this case all HNI HPAI agents are people who have reached maturity because they already have a KTP; not forced, namely HNI HPAI never coerce new members or agents to buy products. In fact, management never reduces the rank of an agent if the agent is not shopping.

Observations in the field show that the average sale and purchase transactions carried out by HPAI HNI stock agents do not mention sighat, namely the consent from the seller and qobul from the recipient when making the sale and purchase. In the discussion of jurisprudence, sighat in terms of buying and selling does not always have to be in the form of speech. Because this pillar of sighat is the understanding of the scholars from the hadith of the prophet who say that buying and selling must be consensual; some scholars say that consensuality can be identified by speechso that this sighat is entered in the pillars of buying and selling. However, some scholars say that consensual and consensual return to urf, that is, if in a certain place the custom of buying and selling transactions is carried out without saying sighat then this is considered valid.284

The object or item being traded is one of the pillars in buying and selling. Terms of goods being traded must be lawful. In HNI HPAI, this has been fulfilled because the goods being traded are goods that already have a halal label from the MUI. In the HNI HPAI, there are two objects or goods that are traded, namely the physical goods and points from the items contained in the HSIS Online HNI HPAI. Among the HNI HPAI products are:

\subsection{Herbs Product}

Andrographis cantella (maintains liver function), Billbery (helps eye health), Biosir (helps relieve hemorrhoids), Carnocap (helps with cancer conditions), Deep Squa (supplements helps maintain health), Diabextrac (helps diabetes symptoms), Gamat capsules (relieves diabetes) pain), Ginextrac (launches urination), Habbasauda (maintains endurance), Harumi (reduces body odor), Langsingin (reduces fat), Laurik (relieves joint pain), Magafit (helps maintain the digestive tract), Noni (relieves high blood pressure), Habbasauda sofgel oil (maintains a healthy body), synergy herbal oil (relieves aches and pains), olive oil sofgel (maintains body immunity), Mustika dara (helps with female problems), n-green (maintains endurance), gotu kola HS (helps blood circulation), procumin vit E rejuvenates the skin), procumin propolis (prevents premature aging of cells), rosella HS (maintains a healthy body), siena (launches bowel movements), spirulina (overcomes anemia), truson (maintains male stamina).

\subsection{Health Food and Beverage}

Centella tea synergy (distinctive flavor tea), premium dates syrup (maintains body health), deep olive (reduces cholesterol), etta goat milk (supplements vitamins in the body), extra food (maintains body health), HPAI Coffee (restores stamina), Janna cold tea (provides freshness), Janna hot tea (provides warmth), 7 elements coffee (restores stamina), Multiflora original honey (complements vitamin needs), Premium original honey (complements vitamin needs), Bitter honey (complements vitamin needs) ), Honey s keep (complete the needs of vitamins), Olive oil (for skin beauty), Sari dates Helathy dates (for body health), Stim fiber (to help endurance) 


\subsection{Cosmetic and Home Care}

Beauty day cream (protects skin from the sun), Beauty nihgt cream (keeps skin healthy), Deep beauty (makes skin smooth), Green wash detergent (prevents dirt from sticking back), Green wash softener (provides softness), Hibis (health femininity), HNI Body wash (protects skin health), HNI Shampoo (protects the scalp), Pgh children with grape flavor (cleans and protects children's teeth), Pgh children taste strawberry (cleans and protects children's teeth), Pgh children taste fruity (clean and protects children's teeth), HPai herbal toothpaste (cleaning and protecting teeth), clove herbal toothpaste (cleaning and protecting teeth), herbal propolis toothpaste (cleaning and protecting teeth) and protects teeth), sensitive herbal toothpaste (cleans and protects teeth), Promol 12 (animal and fish feed supplements), transparent collagen soap (treats skin), transparent honey soap (cleans skin), transparent propolis soap (moisturizes skin).

\subsection{Fashion and Lifestyle}

HNI Hijab, written Mushaf, Quran asy-shifa, Quran bukhoro, Sarong hni fiesta super.

\subsection{Marketing Tools}

Product brochures, CD album hpai, support system 285 Package Either physical or item points are the same rights or property of an agent who is shopping at a stock agent if the agent or person who shopped has an ID number because he has been registered as an HNI HPAI agent.

From the research results, it is found that there are agents who do not sell goods as a whole, namely only selling physical goods but not selling points of goods in HSIS Online. Related to this, it is necessary to specify that if the agent who is shopping is an agent who has an ID number, then he is obliged to sell the whole item, namely physically and in points. However, if the agent who is shopping is a person who does not have an ID number then this is lawful to do because in terms of selling points it can be done if the agent or the person shopping already has a number MLM companies that can grow large and last long are MLM companies that have a support system. In good network marketing, there is a support system that functions as a business school as well as a very positive environment for growth and success. See Wirandinata, Ida Bagus, "The role of a support system in supporting the success of distributors (a study at the Tiianshi Multi Level Marketing company in Lion Raja City in 2013)" V01. 4 No. 1 (2014): p. 4.

Interview with a stock agent herlinda (PSD) in Air Joman Asahan. The interview was conducted at his house on 2 October 2019 ID. Sometimes there are also agents or people who shop who do not need points but only need physical consumption for healthy drugs. This is legally allowed on condition that the price is the consumer value, not the member price.

\section{Conclusion}

The principle of buying and selling transactions through MLM HNI HPAI in BC Tanjungbalai has followed the principles of buying and selling transactions which have been regulated in Islamic law. This is proven by the fulfillment of the terms and conditions of sale and purchase at BC Tanjungbalai. BC Tanjungbalai also prohibits buying and selling transactions that are not allowed in Islam, such as buying and selling that contain elements of gharar, maysir, usury, ihtikar and others. 


\section{References}

A. Djazuli. (2011). Laws of Fiqh: Principles of Islamic Law in Solving Practical Problems, (Jakarta; Kencana)

Abdullah, Fahmi. (2014) "Understanding and Practicing Surah Al Jumuah Verse 9-10 (Case Study on Traders in the Ampel Mosque Environment in Surabaya)," in JESTT Journal, Vol. 1 No. 1 (January)

Abdurrohman. (2016). "Analysis of the Contract Implementation is Jualah in MLM (Study on Marketing Plan Www. Jama Hert. Network)", in the journal Al-Is, Vol. 13

Adil, U. (2017). Sharia Business in Indonesia Law \& Its Applications, Jakarta: Mitra Wacana Media.

Afif, Mufti. (2018). "Multi Level Marketing (MLM) Marketing System in terms of Shari'ah Economic Law", in the journal Islamic Studies, Vol. 13 N0. 2

Akmal, Fauzul and Evawati. (2012). "The Relationship between Employee Motivation and Integration at PT. Legrand Indonesia, Jakarta "in Binoculars: Journal of Management and Business, Vol. 1 No. 1

Amin,M. et al. (2019). Marketing Communication Strategy To Improve Tourism Potential. Budapest International Research and Critics Institute-Journal (BIRCI-Journal). P. 160166.

Bhinadi, Ardito. (2018). Muamalah Syar'iyyah Hidup Barokah, (Yogyakarta: DeePublish)

Bin Bayyih, Abdullah. (2011). Maqashid Al-Syariah Bi Ushul Fikih, london:Muassasah alfurqon li at-taurat al-Islam, tt bin Ismail Al-Amir Ash-Shan'ani, Muhammad, Subulussalam Translation Volume II, Jakarta: Darus sunnah pers.

Boni, Supriadi Yosup. (2017). What's Wrong with MLM? Disclaimer 22 Prohibition of Multi Level Marketing, (Jakarta: Pustaka Al-Kautsar),

Budi Utomo, Setiawan. (2003). Actual Fiqh, Cet I, Jakarta: Gema Insani Press.

Budiantoro, Risanda Alirasta, Reisanda Najmi Sasmita, Tika Widiastuti. (2018) "The Economic System (Islam) and the Prohibition of Riba in a Historical Perspective", in Islamic Economic Scientific Journal, Vol. 4 No. 1 (March): 2477-6157

Dianto, E, et al. (2020). BNI Marketing Strategy for Credit Cards in Dealing Global Competition in State Bank Indonesia (Persero) Tbk Banda Aceh Branch Office. Budapest International Research and Critics Institute-Journal (BIRCI-Journal). P. 11341146

Harefa, Andreas. (1998). Multilevel Marketing, Jakarta: Gramedia Pustaka Utama.

Harizan. (2017). "Efforts to Prevent the Development of Money Games in Indonesia" in the Journal of Syari'ah Science and Islamic Banking, Vol. 2. No. 1 : 2089-7227

Harun, Fiqh Muamalah. (2017). (Surakarta: Muhammadiyah University Press),

Hasan, Akhmad Farroh. (2018). Fiqh Muammalah From Classical to Contemporary (Teroi dan Praktik), (Malang: UIN-Maliki Malang Press),

Hastati, Netty et al. (2005). Islam and Psychology, Jakarta: PT. Raja Grafindo Persada.

Helaluddin, Hengki Wijaya. (2019). Qualitative Data Analysis: A Review of Theory and Practice, (Makasar: Jaffray Theological College)

Hendriyani, Susi and Soni A. Nulhaqim, "The Effect of Dan Training Guidance in Cultivating the Entrepreneurial Spirit of the Foster Partners

PT. (Persero). (2008) Pelabuhan Indonesia 1 Cabang Dumai "In Padjajaran Population Journal, Vol. 10 No. 2.

Herman. (2008). "Development of an Effective Discipline Development Model on the Performance of Civil Servants", in the Journal of Civil Service Policy and Management, (November), Vol. 2 No. 2 
Husna, Nadia Amira and Nurani Latifah. (2018) "Application of Human Resource Management Principles in Kampung Cokelat Blitar" in Iqtisaduna Journal, : 2460-805 Vol. 4 No. 1

Ibn Hajar al Atsqolani, Syihabuddin, Fath Al Bari, juz V, In Maktabah Syamilah

Ichsan, Nurul, "Work, Business and Success According to Islam" in a Journal

The Journal of Tauhidinomics, (2015): 167-182 Vol. 1 No. 2

Idri. (2017). Economic Hadith: Economics in the Perspective of the Prophet's Hadith, (Jakarta: PT. Kharisma Putra Utama)

Ilyas, Musyfikah. (2017). "Certification and Labeling of Halal Products in the Perspective of Maslahat", in the Al-Qadau Journal of Islamic Family Justice and Law, Vol. 4 No. 2 (December)

Marlizar, et al. (2020). The Role of Market Orientation and Creativity in Affecting the Marketing Performance of Market Traders in Aceh Market Banda Aceh City. Budapest International Research and Critics Institute-Journal (BIRCI-Journal).P. 1114-1127

Nuraini, Putri. (2019). "The Economic Impact of Ihtikar and Siyasah Al-Ighraq in the Concept of Buying and Selling", in Al-Hikmah: Journal of Religion and Science, Vol. 16 No. 1 (April)

Pandelaki, Margojte Treisje. (2018). "The Influence of Team Work and Work Culture on Employee Performance of the Titian Budi Luhur Foundation in Parigi Mouton District" In Journalist Journal, Vol. 6 No. 5 (May

Permana, Yudi and Lenny Yanthiani.(2020) Urgency and Application of Qawa'id Al Fiqhiyah About the Concept of Fii Alakhdzi Bi Arrukhsoh in Sharia Economic Development, in the journal al-kharaj: Journal of Islamic economics, finance and business, Vol. 2 No. 3 (March

Poerwadaminta, Big Indonesian Dictionary, Jakarta: PT. Bumi Aksara

Prabu Mangkunegara, Anwar. (1976) Human Resources Company, Youth Rosdakarya: Bandung, 2005

Pranatawijaya, Viktor Handrianus, Widiatry, Ressa Priskila, Putu Bagus Adidyana Anugrah Putra. (2019)."Developing a Web-Based Survey Questionnaire Application Using the Likert and Guttman Scale" in the Journal of Science and Informatics, (November): 2598-5841 V01. 5 No. 2

Prasetyo, Yoyok Sharia. (2018). Economics, (Bandung: Aria Mandiri Group)

Priansa, Donni. (2014). Human Resource Planning and Development,Bandung: Alfabeta.

Pudjiharjo, HM and Nur Faizin Muhith. (2019). Fikih Muamalah Islamic Economics, (Malang: UB Press),

Putra, Muhammad Deni and Frida Amelia. (2019). "The Impact of Ihtikar on Market Mechanisms in an Islamic Perspective", in Imara Journal, Vol. 3 No. 2 (December):

Qomar, Mujamil. (2007). Management of Islamic Education, Surabaya: Erlangga.

Quraisy Shihab. (2008).M, Tafsir Al-Mishbah volume 7, Jakarta: heart lantern.

Sugiarto, Tommi. (2017). "Evaluation of Teamwork Process in Timika Business" in the Journal of Management and Business Start-Up, vol. 2 no. 1 (April)

Sukirman, Hartati et al. (2009). Education Administration and Supervision, Yogyakarta: UNYPress.

Sula, Muhammad Syakir. (2004). Sharia Insurance (Life And General): Concepts and Operational Systems, (Jakarta: Gema Insani Press)

Sulaiman. (2018). "The Significance of Maqashid Sharia in Islamic Economic Law" in the journal Sharia and Law Dictum, Vol. 16 No. 1 (July):

Sulistiani, Siska Lis. (2018)."Analysis of Maqashid Sharia in the Development of Halal Industry Law in Indonesia" in the Journal of Law And Justice, (October) Vol. 3 No. 2 
Supriadi, Akhmad. (2017). "System as Philosophy (Jasser Auda's New Offer for the Development of Contemporary Islamic Law)," In the Journal of Religion and Community Studies, Vol. 13 No. 2 (December):

Supriadi. (2018). The Concept of Price in Islamic Economics, (Bogor: Guipedia Publisher). Suryabrata, Sumadi. (1993). Educational Psychology, Jakarta: PT. Raja Grafindo Persada.

Susiawati, Wati. (2017). "Buying and Selling in the Present Context", in the Journal of Islamic Economics, Vol. 8 No. 2 (November):

Syafrida Hafni Sahir. (2020). Management Ideas, (Medan: Our Writing Foundation)

Syafrudin, Muhammad, et al. (2016). "Motivation for wearing the hijab for Islamic students at the state university of Jakarta" in the al-Quran study journal, Vol. 12 No. 2

Tyas Kuncoro, Anis. (2009). Multilevel Marketing Business Concepts in the Perspective of Syari'ah Economics in Multilevel Marketing Business Concepts, Sultan Agung VOL XLV NO. 119 September - November.

Uhbiyati, Nur. (1997). Islamic Education 2, Bandung: CV. Pustaka Setia.

Umam, Muhammad Khairul. (2018). "Imam of the Prophets: Tracing the Leadership and Managerial Trails of the Prophet Muhammad" in the journal Al Hikmah, (March) Vol. 6 No. 1

Usman, Husaini and Purnomo Setiady Akbar. (2003). Social Research Methodology, Jakarta: PT Bumi Aksara.

Wahid, Abdul. (2018). "Classical Sharia Maqashid Reform Towards a Contemporary Perspective" in the Journal of Islamic Education and Institutions, Vol. 9 No. 2 (October):

Wahidin, Ade. (2018). "The Principle of Mutual Will in Islamic Economic Transactions (Analytical Tafsir of Surat An-Nisa [4] Verse 29)," in Ad-Deenar: Journal of Islamic Economics and Business, Vol. 2 No. 2

Wahyuddin. (2014). "God's intentions in establishing sharia in the perspective of al-syatibi" in Sharia: Journal of Law and Thought, Vol. 14 No. 1

Wahyudi, Firman. (2014). Multi Level Marketing in Muamalah Jurisprudence Studies, in AlBanjari Vol. 13, No. 2, July-December.

Wardah, Yuspin. (2007). "Application of Sharia Principles in the Implementation of the Murabahah Contract," in the Journal of Legal Studies, Vol. 10 No. 1 (March)

Warson Munawwir, Ahmad. (1984). Arabic-Indonesian Dictionary, Yogyakarta: PP alMunawwir,

Wirandinata, Ida Bagus. (2014). "The role of a support system in supporting the success of distributors (a study at the Tiianshi Multi Level Marketing company in the Lion King City in 2013)" V01. 4 No. 1 